\title{
NUTRITIONAL REGULATION AND TISSUE SPECIFICITY OF GENE EXPRESSION FOR PROTEINS INVOLVED IN HEPATIC GLUCOSE METABOLISM IN RAINBOW TROUT (ONCORHYNCHUS MYKISS)
}

\author{
S. PANSERAT*, E. PLAGNES-JUAN AND S. KAUSHIK \\ Laboratory of Fish Nutrition, INRA-IFREMER, 64310 St-Pée-sur-Nivelle, France \\ *e-mail: panserat@st-pee.inra.fr \\ Accepted 2 May 2001
}

\begin{abstract}
Summary
Rainbow trout (Oncorhynchus mykiss) are known to use dietary carbohydrates poorly. One of the hypotheses to explain the poor utilisation of dietary glucose by these fish is a dysfunction in nutritional regulation of hepatic glucose metabolism. In this study, we obtained partial clones of rainbow trout cDNAs coding for a glucose transporter (Glut2), and for the enzymes 6-phosphofructo2-kinase/fructose-2,6-bisphosphatase (6PF-2K/F-2,6BPase), fructose-1,6-bisphosphatase (FBPase) and pyruvate kinase (PK). Their deduced amino acid sequences were highly similar to those of mammals (up to $80 \%$ similarity). In a

of glucose from the liver. Moreover, whereas PK and FBPase gene expression was high irrespective of the nutritional status, levels of hepatic 6PF-2K/F-2,6BPase mRNA were higher in fish fed with carbohydrates than in fish deprived of food. The high levels of hepatic PK, Glut2 and $6 \mathrm{PF}-2 \mathrm{~K} / \mathrm{F}-2,6 \mathrm{BPase}$ gene expression observed in this study suggest a high potential for tissue carbohydrate utilisation in rainbow trout. The persistence of a high level of FBPase gene expression suggests an absence of regulation of the gluconeogenic pathway by dietary carbohydrates.
\end{abstract} study of nutritional regulation, the Glut2 gene was highly expressed in the liver irrespective of the nutritional status of the trout, in agreement with the role of this transporter in the input (during refeeding) and output (during fasting)
Key words: liver metabolism, glucose metabolism, glucose transporter, fructose bisphosphatase, pyruvate kinase, bifunctional enzyme, trout, Oncorhynchus mykiss.

\section{Introduction}

Improvement of dietary carbohydrate utilisation by fish has practical implications in aquaculture. The rainbow trout (Oncorhynchus mykiss) is an interesting model species recognised for its low levels of carbohydrate utilisation (Palmer and Ryman, 1972; Bergot, 1979; Cowey and Walton, 1989; Wilson, 1994; Moon and Foster, 1995). Analysis of glucose utilisation such as glucose phosphorylation (Cowey and Walton, 1989; Moon and Foster, 1995), glucose transporters (Wright et al., 1998) and insulin receptors (Mommsen and Plisetskaya, 1991; Parrizas et al., 1994), in target tissues is important in order to obtain an overall view of low dietary glucose utilisation in this carnivorous fish species. One hypothesis to explain the poor utilisation of dietary glucose by fish is a dysfunction of nutritional regulation between two major metabolic pathways in the liver: (i) a low capacity to store excess glucose in the postprandial stage (glycogen synthesis or lipogenesis) (Cowey and Walton, 1989; Wilson, 1994) and/or (ii) persistent highly active hepatic glucose production when carbohydrates are provided in the diet (Panserat et al., 2000b; Panserat et al., 2001). Indeed, we have recently shown, in rainbow trout, the induction of expression of glucokinase, the first enzyme in the glycolytic pathway, and the absence of inhibition of glucose-6-phosphatase, the last enzyme in hepatic glucose production (Panserat et al., 2000a; Panserat et al., 2000b).

The aim of the present study was to analyse two key hepatic glycolytic enzymes: (i) 6-phosphofructo-2-kinase/fructose2,6-bisphosphatase, otherwise termed the bifunctional enzyme (6PF-2K/F-2,6BPase, EC2.7.1.105/EC3.1.3.46) (Pilkis and Granner, 1992; Pilkis et al., 1995), which produces fructose 2,6-bisphosphate, a key allosteric regulator of glycolysis/gluconeogenesis in the liver (Pilkis et al., 1995), and (ii) L-type pyruvate kinase (PK, EC2.7.1.40), which catalyses the conversion of phosphoenolpyruvate to pyruvate, the last step in glycolysis (Yamada and Noguchi, 1999). We also studied the key gluconeogenic enzyme fructose-1,6bisphosphatase (FBPase, EC3.1.3.11); this enzyme catalyses the conversion of fructose-1,6-bisphosphate to fructose-6phosphate (Marcus et al., 1987). Finally, we looked for a type2 glucose transporter (Glut2) in the liver of rainbow trout. This transporter maintains the same glucose concentration between the extra and intracellular (hepatocyte) media because of its high $K_{\mathrm{m}}$ for glucose (Thorens, 1992).

In mammals, the expression of PK, 6PF-2K/F-2,6BPase and 
Glut2 proteins is positively controlled by feeding, specifically by dietary carbohydrates (Thorens, 1992; Pilkis et al., 1995; Yamada and Noguchi, 1999); this induction potentiates dietary glucose utilisation in the liver. However, kinase activity of 6PF2K/F-2,6BPase, which generates the fructose-2,6-bisphosphate, is also positively dependent on protein phosphatase $2 \mathrm{~A}$ activity. The mechanism of induction of these proteins is mediated largely by induction of their gene expression even though, for the Glut2, the regulation of gene expression in the liver is rather complex (Thorens, 1992; Rencurel et al., 1996; Pilkis et al., 1995; Yamada and Noguchi, 1999). In contrast, feeding and dietary carbohydrates inhibit FBPase gene expression (ElMagrabi et al., 1982; El-Magrabi et al., 1988).

Nutritional regulation of the activities of PK, FBPase and 6PF-2K/F-2,6BPase has been studied previously in fish (Cowey et al., 1977; Cowey et al., 1981; Hilton and Atkinson, 1982; Fideu et al., 1983; Petersen et al., 1987; Lupianez et al., 1989; Garcia de Fructos and Baanante, 1994; Shikata et al., 1994; Shimeno et al., 1995; Meton et al., 1999a; Meton et al., 1999b; Tranulis et al., 1996; Borrebaek and Christophersen, 2000). It seems that there is an increase in the activities of PK and $6 \mathrm{PF}-2 \mathrm{~K} / \mathrm{F}-2,6 \mathrm{BPase}$ in response to feeding, although no clear data on the mechanism (transcriptional, posttranscriptional, post-translational) involved in this nutritional regulation are available except for the $6 \mathrm{PF}-2 \mathrm{~K} / \mathrm{F}-2,6 \mathrm{BPase}$ in gilthead seabream (Sparus aurata) (Garcia de Fructos and Baanante, 1994; Meton et al., 1999a; Meton et al., 1999b). No specific inhibition of hepatic FBPase activity in response to feeding has been observed in perch (Perca fluviatilis) or salmon (Salmo salar) (Tranulis et al., 1996; Borrebaek and Christophersen, 2000) whereas in European seabass (Dicentrarchus labrax) and gilthead seabream inhibition of FBPase activity in response to feeding has been demonstrated (Garcia-Rejon et al., 1996; Meton et al., 1999b). Finally, the existence of a mammalian-type glucose transporter (Glut) in fish is still a matter of debate; for example, studies using mammalian anti-Glut antibodies suggest, in tilapia (Oreochromis niloticus), a very limited distribution of Glut1 and the complete absence of Glut4 (Wright et al., 1998), whereas recent studies demonstrate the existence of Glut1 and Glut4 cDNAs in rainbow trout and brown trout (Salmo trutta), respectively (Teerijoki et al., 2000; Planas et al., 2000).

In rainbow trout, no molecular data for $6 \mathrm{PF}-2 \mathrm{~K} / \mathrm{F}-2,6 \mathrm{BPase}$, PK, FBPase and Glut2 proteins are yet available. The aim of this study was the partial cloning of PK, GLUT2, FBPase and $6 \mathrm{PF}-2 \mathrm{~K} / \mathrm{F}-2,6 \mathrm{BPase} \mathrm{cDNAs}$ expressed in the liver, followed by the analysis of their expression in different tissues and in fish under different nutritional conditions.

\section{Materials and methods Fish and diets}

Juvenile immature rainbow trout (Oncorhynchus mykiss) were grown for 10 weeks at $18{ }^{\circ} \mathrm{C}$ at the INRA experimental fish farm (Donzacq, France) and fed with $(20 \%)$ or without $(<0.5 \%)$ carbohydrates, as described previously (Panserat et
Table 1. Origin of the cDNA sequences used in the comparative analysis

\begin{tabular}{lc}
\hline mRNA sequence & $\begin{array}{r}\text { GenBank } \\
\text { accession num }\end{array}$ \\
\hline PK sequences & \\
Human Homo sapiens & $\mathrm{M} 15465$ \\
Rat Rattus norvegicus & $\mathrm{M} 11709$ \\
Mouse Mus musculus & $\mathrm{D} 63764$ \\
Glut2 sequences & \\
Human Homo sapiens & $\mathrm{J} 03810$ \\
Chicken Gallus gallus & $\mathrm{Z} 22932$ \\
6PF-2K/F-2,6BPase sequences & \\
Rat Rattus norvegicus & $\mathrm{Y} 00702$ \\
Bull frog Rana catesbeiana & $\mathrm{D} 25223$ \\
Gilthead seabream Sparus aurata & $\mathrm{U} 84724$ \\
FBPase sequences & \\
Human Homo sapiens & $\mathrm{D} 26055$ \\
Rat Rattus norvegicus & $\mathrm{M} 86240$ \\
Mouse Mus musculus & $\mathrm{AJ} 132693$ \\
Caenorhabditis elegans & AJ271466
\end{tabular}

6PF-2K/F-2,6BPase, 6-phosphofructo-2-kinase/fructose-2,6bisphosphatase; PK, pyruvate kinase; FBPase, fructose-1,6bisphosphatase; Glut2, glucose transporter type 2.

al., 2000a; Panserat et al., 2000b). On the sampling day, the fish were fed once and killed $6 \mathrm{~h}$ and $24 \mathrm{~h}$ after feeding. Fooddeprived fish were deprived for 4 days. Tissues (liver, muscle, heart, kidney, brain) were quickly removed, frozen in liquid nitrogen and stored at $-80^{\circ} \mathrm{C}$.

\section{RNA isolation and reverse transcription}

Total RNA was extracted from rainbow trout tissues as described by Chomczinski and Sacchi (Chomczinski and Sacchi, 1987). cDNA was obtained by annealing $2 \mu \mathrm{g}$ of total RNA with $1 \mu \mathrm{g}$ of random primers and incubating with AMV reverse transcriptase (Boehringer, Roche Molecular Biochemicals, Germany) for $1 \mathrm{~h}$ at $42^{\circ} \mathrm{C}$.

\section{Cloning of partial 6PF-2K/F-2,6BPase, PK, FBPase and Glut2 cDNAs}

6PF-2K/F-2,6BPase, PK, FBPase and Glut2 sequences from different species (see Table 1) were compared using the Clustal-W multiple alignment algorithm (Higgins and Sharp, 1989). The sequences of the upstream and downstream (degenerate) primers are presented in Table 2. cDNA $(1 \mu \mathrm{l})$ was amplified by polymerase chain reaction (PCR) using $100 \mathrm{pmol}$ of the degenerate primers in a reaction mixture containing $2 \mathrm{mmoll}^{-1} \mathrm{MgCl}_{2}, \quad 50 \mathrm{mmoll}^{-1} \mathrm{KCl}$, $20 \mathrm{mmol}^{-1}$ Tris- $\mathrm{HCl}, 0.25 \mathrm{mmol}^{-1} \mathrm{dNTP}$ and 2.5 units of Taq polymerase (Boehringer, Roche Molecular Biochemicals, Germany). 35 cycles of denaturation for $1 \mathrm{~min}$ at $94{ }^{\circ} \mathrm{C}$, annealing at $56^{\circ} \mathrm{C}$ for $30 \mathrm{~s}$, and extension at $72^{\circ} \mathrm{C}$ for $30 \mathrm{~s}$ were performed. PCR products were subjected to electrophoresis in $1 \%$ agarose gels and fragments of the expected size range were purified (Micropure System, Amicon, USA). The purified DNA fragments were inserted into the $\mathrm{pCR}^{\mathrm{TM}} \mathrm{II}$ plasmid and 
Table 2. Primers used for enzyme cDNA cloning by RT-PCR (degenerate primers) and gene expression analysis

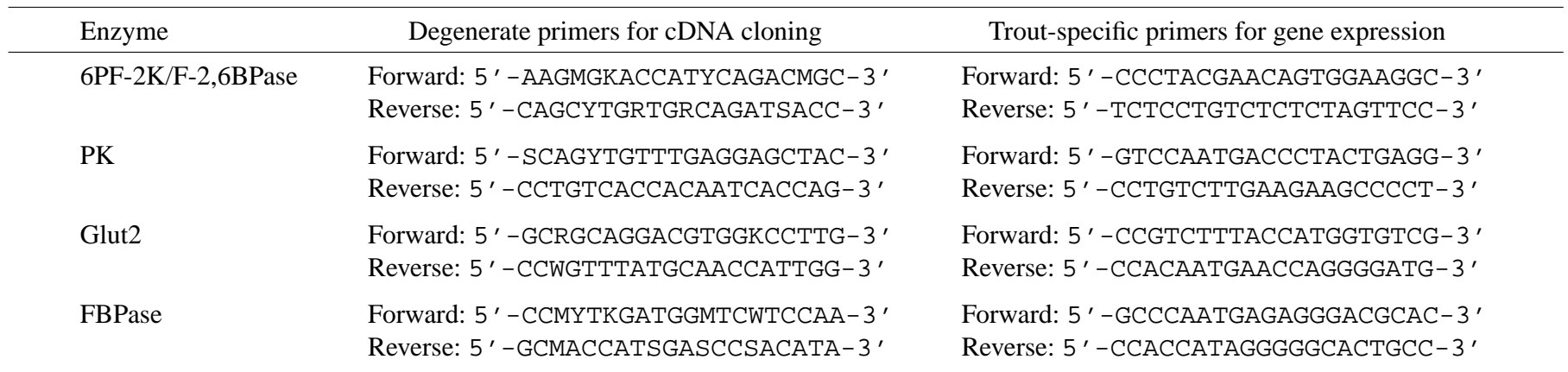

Y, C/T; M, A/C; W, A/T; K, G/T; R, A /G; S, G/C.

6PF-2K/F-2,6BPase, 6-phosphofructo-2-kinase/fructose-2,6-bisphosphatase; PK, pyruvate kinase; FBPase, fructose-1,6-bisphosphatase; Glut2, glucose transporter type 2 .

RT-PCR, reverse transcription-polymerase chain reaction. See Materials and Methods for details.

used for transformation of One Shot ${ }^{\mathrm{TM}}$ competent cells (Invitrogen, Carlsbad, CA, USA). Inserts were detected by EcoRI digestion of the extracted plasmid DNA. Two clones with inserts were sequenced (Cybergène, Evry, France).

\section{Sequence analysis}

Nucleotide sequences (excluding the primer sequences) were compared with DNA sequences from the GenBank database using the basic local alignment search tool (BLAST) algorithm (Altschul et al., 1990). Sequence alignments and percentage of amino acid conservation were assessed with the Clustal-W multiple alignment algorithm using the cloned fish sequence and sequences from other species corresponding to the amplified regions from databases.

\section{Analysis of gene expression \\ Northern analysis}

Extracted total RNA $(20 \mu \mathrm{g})$ samples were electrophoresed in $1 \%$ agarose gels containing $5 \%$ formaldehyde and transferred by capillary onto nylon membrane (Hybond- $\mathrm{N}^{+}$, Amersham, England). After transfer, RNA blots were stained with Methylene Blue to locate $26 \mathrm{~S}$ and $16 \mathrm{~S}$ rRNAs and to determine the amount of loaded RNA. Membranes were hybridized with fish ${ }^{32} \mathrm{P}$-labelled DNA probes labelled by random priming (Stratagene, USA) and recognizing partial rainbow trout $6 \mathrm{PF}-2 \mathrm{~K} / \mathrm{F}-2,6 \mathrm{BPase}, \mathrm{PK}$, FBPase and Glut2 cDNAs. After stringent washing $(2 \times \mathrm{SSC}, 0.1 \% \mathrm{SDS}$ for $20 \mathrm{~min}$; $1 \times$ SSC, $0.1 \%$ SDS for $20 \mathrm{~min}$; $0.2 \times$ SSC, $0.1 \%$ SDS for $15 \mathrm{~min}$ ), the membranes were exposed to X-ray film and the resulting images were quantified using Visio-Mic II software (Genomic, France).

\section{$R T-P C R$ analysis}

cDNAs were amplified by PCR using specific primers chosen from the partial sequences for rainbow trout 6PF2K/F-2,6BPase, PK, FBPase and Glut2 cDNAs (Table 2). PCR reactions were carried out in a final volume of $25 \mu \mathrm{l}$ containing $1.5 \mathrm{mmoll}^{-1} \mathrm{MgCl}_{2}$ and $4 \mathrm{pmol}$ of each primer, $2 \mu \mathrm{l}$ cDNA and 1 unit of Taq polymerase (Boehringer, Roche
Molecular Biochemicals, Germany). 35 cycles of $20 \mathrm{~s}$ for hybridization (at $57^{\circ} \mathrm{C}$ ), $20 \mathrm{~s}$ for elongation (at $72^{\circ} \mathrm{C}$ ) and $20 \mathrm{~s}$ for denaturation (at $94^{\circ} \mathrm{C}$ ) were performed. The PCR products were characterized by sequencing (Cybergène, Evry, France).

\section{Statistical analyses}

The results are expressed as means \pm S.D. When there were significant differences in variances (one-way analysis of variance, ANOVA), statistical differences between series of data were determined using Tuckey's post-hoc test (Systat 9 software products, SPSS Inc.). Differences were considered significant at $5 \%$.

\section{Results}

The available PK, Glut2, FBPase and 6PF-2K/F-2,6BPase cDNA sequences were aligned and highly conserved regions from different species (Table 1) were identified. Four sets of primers were designed (Table 2) and this made it possible to amplify partially PK, Glut2, FBPase and 6PF-2K/F-2,6BPase mRNAs. RT-PCR were performed on hepatic total RNA extracted from fish fed with or without carbohydrate (for FBPase cloning only). PCR conditions were optimized, and a major amplification product of the expected size was obtained for PK, Glut2, FBPase and 6PF-2K/F-2,6BPase transcripts (data not shown). The fragments were purified, cloned and sequenced. The cDNA sequences of 366 base pairs (bp) (PK), $293 \mathrm{bp}$ (Glut2), $395 \mathrm{bp}$ (FBPase) and $268 \mathrm{bp}$ (6PF-2K/F2,6BPase) (Fig. 1A, Fig. 2A, Fig. 3A, Fig. 4A) were highly similar to those of 'mammalian' genes (Blast algorithm, $p=10^{-56}$ to $10^{-46}, p=10^{-12}$ to $10^{-8}, p=10^{-106}$ to $10^{-11}, p=10^{-72}$ to $10^{-62}$ for PK, Glut2, FBPase and $6 \mathrm{PF}-2 \mathrm{~K} / \mathrm{F}-2,6 \mathrm{BPase}$, respectively). The corresponding amino acid sequences were deduced from the four cDNA sequences and showed open reading frames of 121 (PK), 97 (Glut2), 131 (FBPase) and 89 (6PF-2K/F-2,6BPase) codons highly homologous to 'mammalian' proteins (Blast algorithm, $p=10^{-56}$ to $10^{-42}$, $p=10^{-47}$ to $10^{-45}, p=10^{-47}$ to $10^{-33}, p=10^{-54}$ to $10^{-45}$ for $\mathrm{PK}$, 


\section{S. Panserat, E. Plagnes-Juan and S. KaushiK}

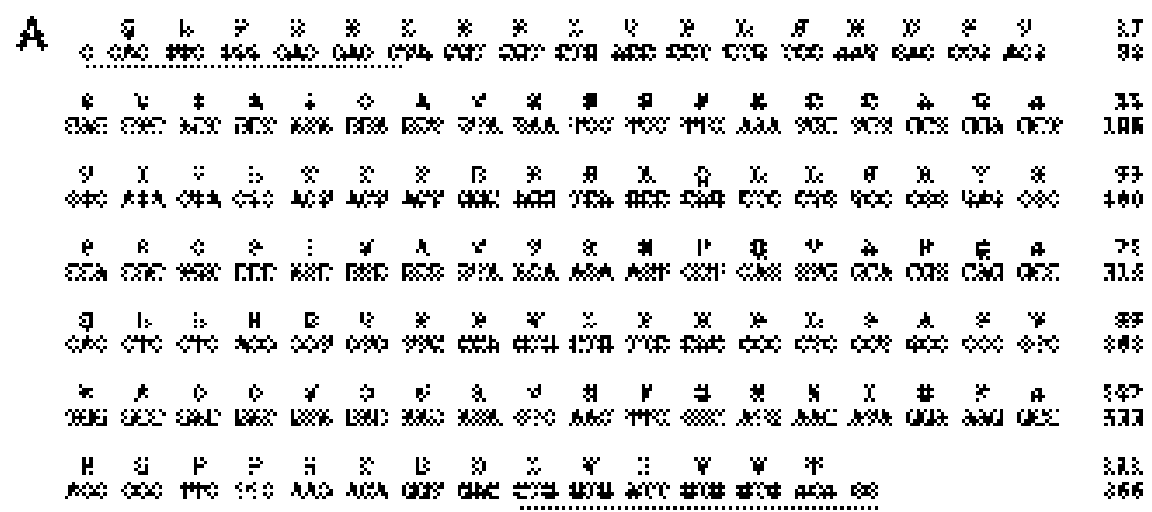

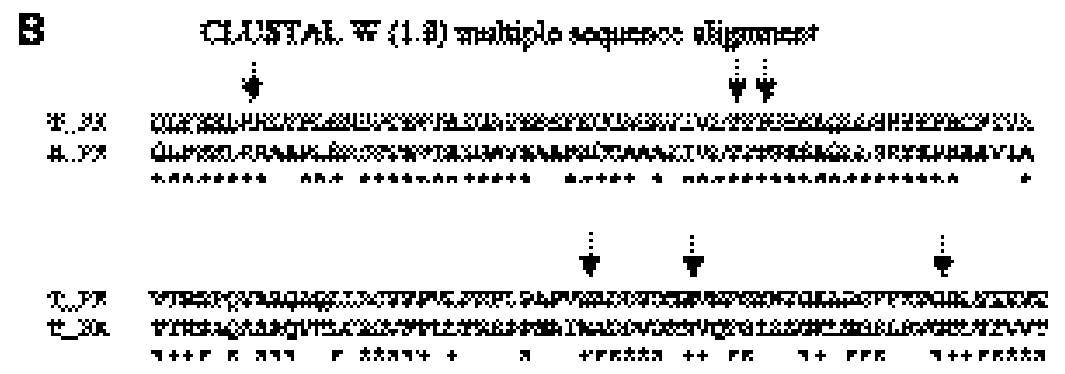

Fig. 1. Partial cloning of the pyruvate kinase (PK) gene in rainbow trout. (A) Nucleotide and deduced amino acid sequences of the rainbow trout PK clone. Underlined letters correspond to the primer sequences. (B) Alignments of the partial amino acid deduced PK cDNA of the rainbow trout (T_PK) (GenBank accession number: AF246146) with human PK (H_PK) (GenBank accession number: P30613). Underlined letters correspond to the primer sequences. Asterisks mark amino acid residues homologous between PKs. Residues involved in the interaction with the allosteric activator fructose-1,6-bisphosphate are marked by arrows (Jurica et al., 1998).

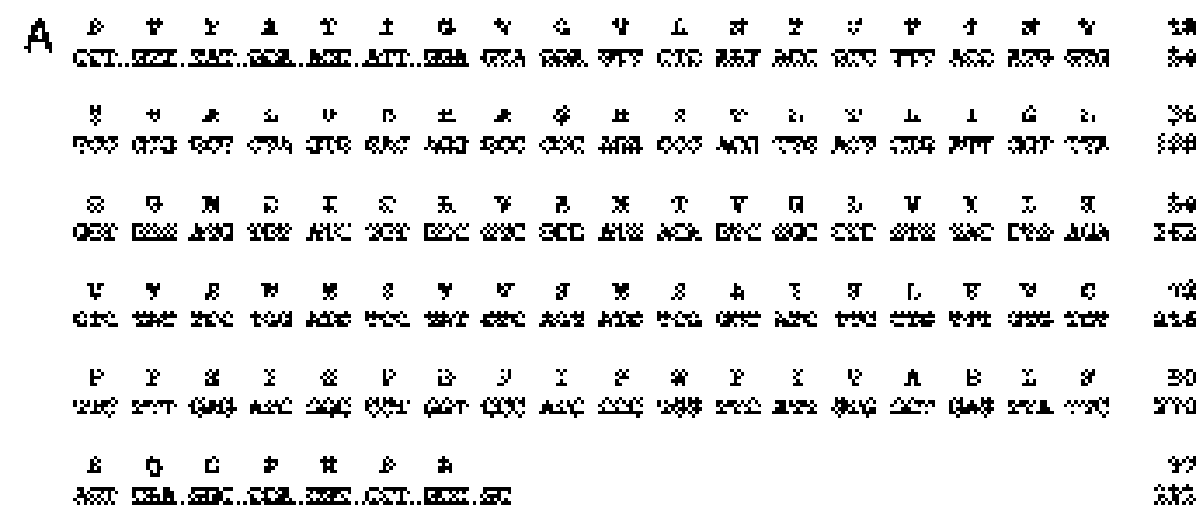

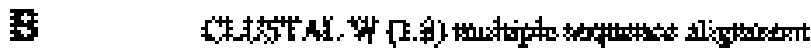

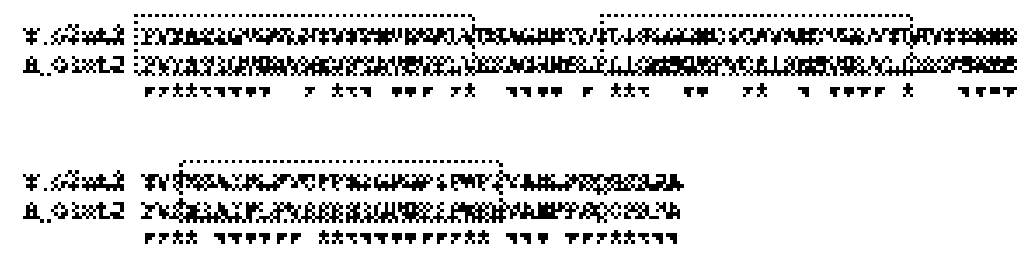

Fig. 2. Partial cloning of the glucose transporter type 2 (Glut2) gene in rainbow trout. (A) Nucleotide and deduced amino acid sequences of the rainbow trout Glut 2 clone. Underlined letters correspond to the primer sequences. (B) Alignments of the partial amino acid sequence deduced from Glut2 cDNA of the rainbow trout (T_Glut2) (GenBank accession number: AF246147) with human Glut2 (H_Glut2) (GenBank accession number: P11168). Underlined letters correspond to the primer sequences. Asterisks mark amino acid residues homologous between Glut2s. Hydrophobic putative transmembrane segments are boxed (Thorens, 1992). 


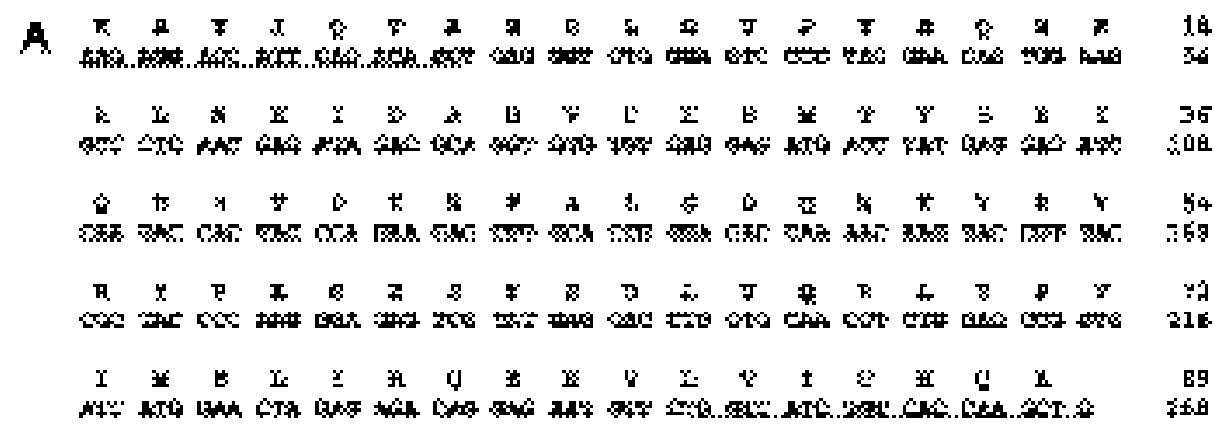

E

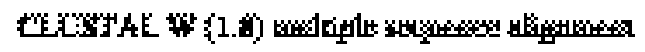

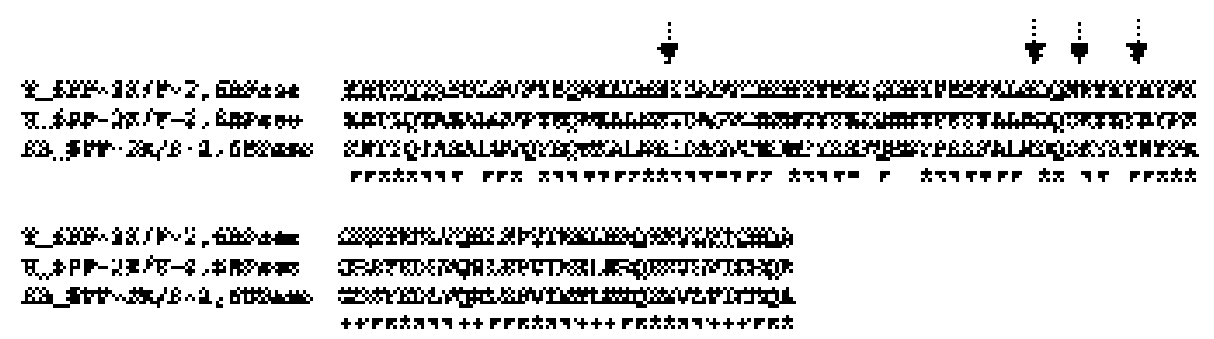

Fig. 3. Partial cloning of the 6-phosphofructo-2-kinase/fructose-2,6-biphosphatase (6PF-2K/F-2,6BPase) gene in rainbow trout. (A) nucleotide and deduced amino acid sequences of the rainbow trout $6 \mathrm{PF}-2 \mathrm{~K} / \mathrm{F}-2,6 \mathrm{BPase}$ clone. Underlined letters correspond to the primer sequences. (B) Alignments of the partial amino acid deduced sequence from 6PF-2K/F-2,6BPase cDNA of the rainbow trout (T_6PF-2K/F-2,6BPase) (GenBank accession number: AF246148) with human 6PF-2K/F-2,6BPase (H_6PF-2K/F-2,6BPase) (GenBank accession number: P16168) and gilthead seabream (Sparus aurata) 6PF-2K/F-2,6BPase (SB_6PF-2K/F-2,6BPase) (GenBank accession number: U84724). Underlined letters correspond to the primer sequences. Asterisks mark amino acid residues homologous between 6PF-2K/F-2,6BPases. Residues marked by an arrow are key residues for the 6PF-2K/F-2,6BPase (Meton et al., 1999a).

Glut2, FBPase and 6PF-2K/F-2,6BPase, respectively) (Fig. 1B, Fig. 2B, Fig. 3B, Fig. 4B).

To analyze the tissue specificity of PK, Glut2, FBPase and 6PF-2K/F-2,6BPase gene expression (Fig. 5), we performed RT-PCR using specific rainbow trout PK, Glut2, FBPase and 6PF-2K/F-2,6BPase primers (Table 2). This RT-PCR was not quantitative, and thus only the presence or absence of a specific mRNA could be determined. PK and Glut2 mRNAs were detected in liver, intestine and kidney but not in muscle, brain or heart (Fig. 5). FBPase mRNA was detected in liver, intestine and kidney but also in muscle, brain and heart of fed fish. Finally, 6PF-2K/F-2,6BPase gene expression was ubiquitous, even not much in brain of fed fish.

As growth rates of rainbow trout fed with $20 \%$ carbohydrates or without carbohydrates were comparable (Panserat et al., 2000a), comparative analysis of the effects of dietary carbohydrates on the regulation of metabolic enzyme expression between fish groups fed different carbohydrate levels was possible. Expression of PK, Glut2, FBPase and 6PF$2 \mathrm{~K} / \mathrm{F}-2,6 \mathrm{BPase}$ genes was analyzed in fish livers by northern blotting (Fig. 6). Single mRNA species for PK and Glut2 cDNAs of approximately $2.2 \mathrm{~kb}$ and $2 \mathrm{~kb}$, respectively, were found (Fig. 6A,B). In contrast, two mRNAs for $6 \mathrm{PF}-2 \mathrm{~K} / \mathrm{F}$ 2,6BPase and FBPase were found (Fig. 6C,D); the major forms were approximately $2 \mathrm{~kb}$ and $2.7 \mathrm{~kb}$ for $6 \mathrm{PF}-2 \mathrm{~K} / \mathrm{F}-2,6 \mathrm{BPase}$ and FBPase, respectively, whereas the minor mRNAs (very weak) were of approximately $1.5 \mathrm{~kb}$ and $2.5 \mathrm{~kb}$ (data not shown). As the expression of the minor fragment is not easy to analyze by northern blotting (level of gene expression is too low), only the major 6PF-2K/F-2,6FBase and FBPase mRNA species were studied in this nutritional analysis.

The effect of fasting and refeeding on gene expression was analyzed. In contrast to expression of PK, FBPase and Glut2 (in which no significant differences were observed between food-deprived and fed fish), it appeared that the level of 6PF$2 \mathrm{~K} / \mathrm{F}-2,6 \mathrm{BP}$ ase gene expression was significantly higher in fish fed with carbohydrates $24 \mathrm{~h}$ after feeding than in food-deprived fish $(P<0.05$, Tukey's test: Fig. 7A-D). Our results indicated that dietary carbohydrates did not induce a specific effect; expression of PK, Glut2, FBPase and 6PF-2K/F-2,6BPase mRNAs were elevated at both $6 \mathrm{~h}$ and $24 \mathrm{~h}$ after feeding, similar to levels in the livers of fish fed with and without carbohydrates (Fig. 7A-D). We also analyzed the effects of the postprandial time on gene expression in fish fed with a specific diet ( $6 \mathrm{~h}$ compared with $24 \mathrm{~h}$ feeding): no significant effect was observed (data not shown).

\section{Discussion}

PK, Glut2, FBPase and 6PF-2K/F-2,6BPase belong to a family of enzymes, such as phosphoenolpyruvate carboxykinase (EC4.1.1.32) and fatty acid synthetase (EC2.3.1.85), whose expression in mammals has been shown to be regulated by dietary carbohydrates (Rencurel and Girard, 


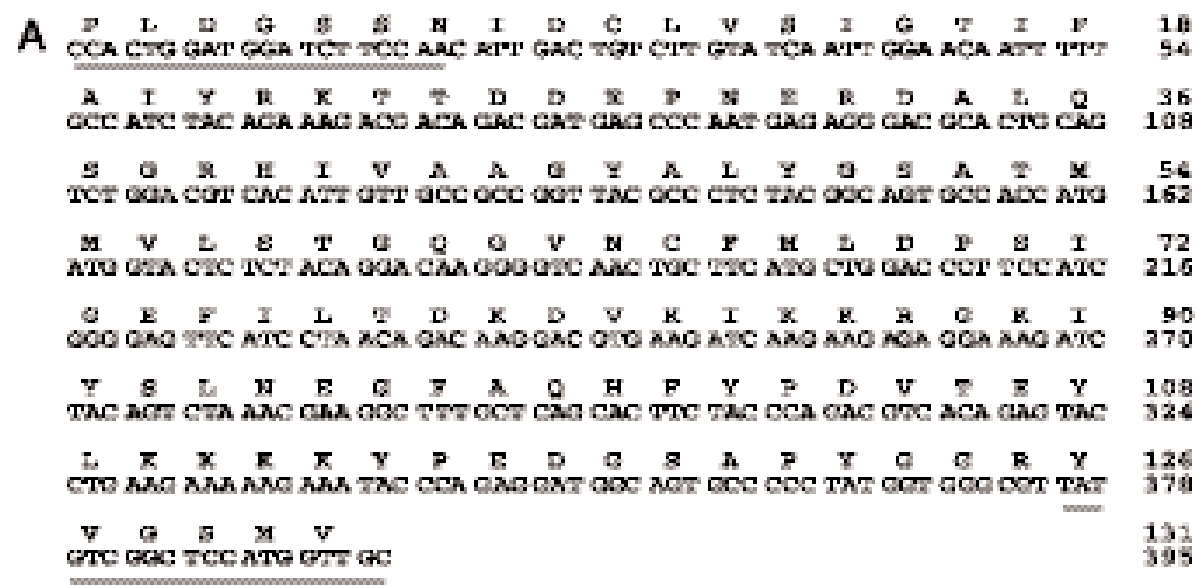

B

C.USTAL. W (1.8) mnitiple requence alignment

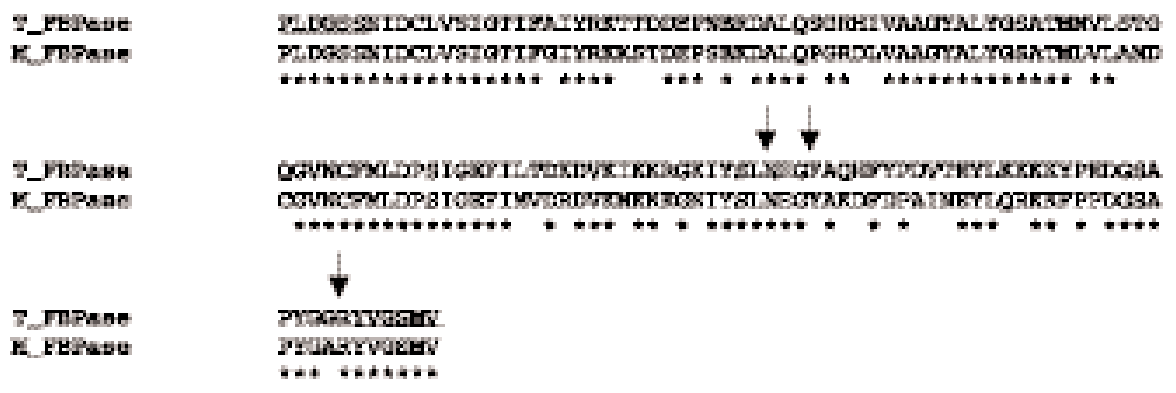

Fig. 4. Partial cloning of the FBPase gene in rainbow trout. (A) Nucleotide and deduced amino acid sequences of the rainbow trout FBPase clone. Underlined letters correspond to the primer sequences. (B) Alignments of the partial amino acid deduced sequence from FBPase cDNA of the rainbow trout (T_FBPase) (GenBank accession number: AF333188) with mouse FBPase (M_FBPase) (GenBank accession number: AJ132693). Underlined letters correspond to the primer sequences. Asterisks mark amino acid residues homologous between FBPases. Conserved residues involved in the interaction with fructose-1,6-bisphosphate are marked by arrows (Ke et al., 1989).

Fig. 5. Tissue specificity of 6-phosphofructo-2-kinase/ fructose-2,6-biphosphatase (6PF-2K/F-2,6BPase), pyruvate kinase (PK), fructose-1,6-bisphosphatase (FBPase) and glucose transporter type 2 (Glut2) gene expression in fooddeprived rainbow trout and fed rainbow trout with $20 \%$ carbohydrates (at $6 \mathrm{~h}$ after feeding). Analysis by nonquantitative RT-PCR ( $N=2$ fish per treatment). Ma, molecular mass marker phiX174 DNA/HaeIII (Promega, USA); N, negative control, i.e. RT-PCR reactions performed without RNA and with reverse transcriptase (other controls made with RNA and without reverse transcriptase were also performed to determine genomic DNA contamination; data not shown). L, liver; $\mathrm{Mu}$, muscle; $\mathrm{H}$, heart; $\mathrm{B}$, brain; $\mathrm{K}$, kidney; I, intestine. The exact lengths of the $6 \mathrm{PF}-2 \mathrm{~K} / \mathrm{F}-$ 2,6BPase, PK, FBPase and Glut2 fragments (205 bp, 300 bp, $288 \mathrm{bp}$ and $222 \mathrm{bp}$, respectively) were determined from known gene sequences. The quality of the first-strand cDNA used in each of the PCR assays was first confirmed by its ability to support the amplification of FBPase and 6PF-2K/F-2,6BPase cDNAs, and the failure to detect the presence of PK and Glut2 mRNA in certain tissues does not imply poor quality of RNA samples or a low-efficiency reverse transcription reaction.
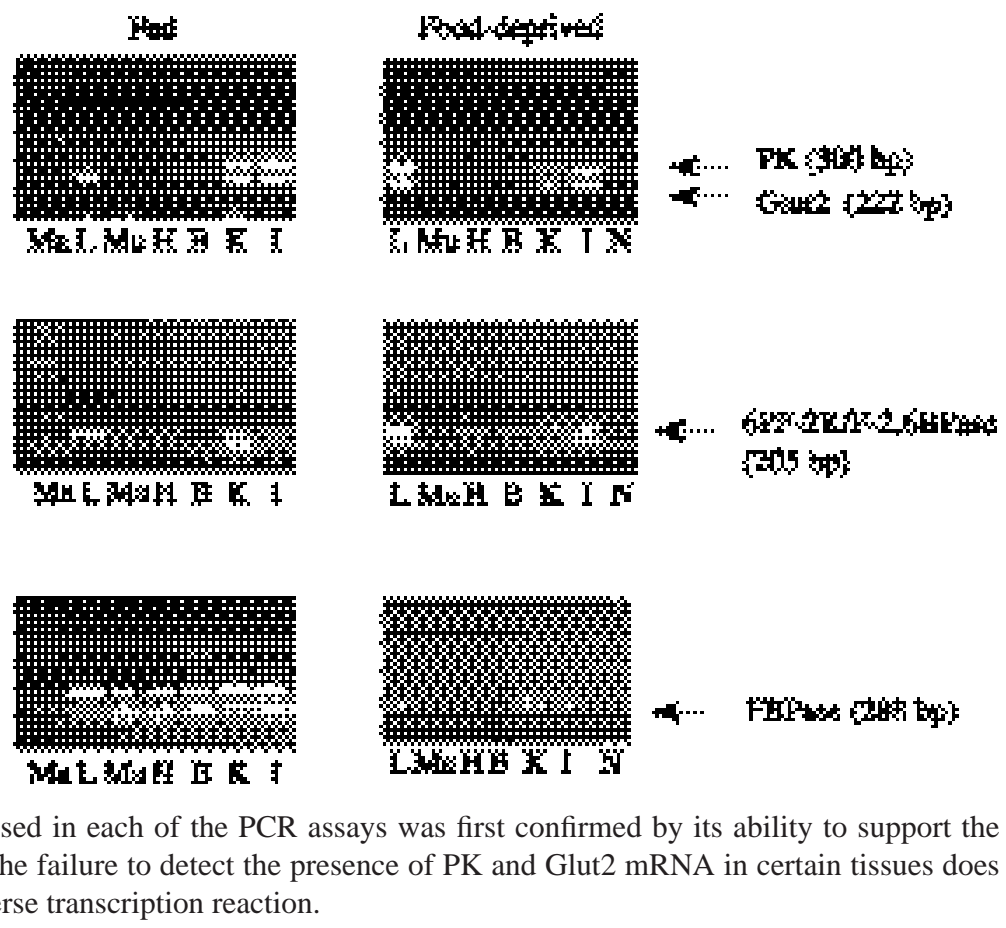
1998). In fish, literature data in this area are scarce. Although a formal proof will await the cloning of the full-length cDNA sequence, the high similarity between the cDNA sequences of hepatic PK, Glut2, FBPase and 6PF-2K/F-2,6BPase in rainbow trout and of the PK, Glut2, FBPase and 6PF-2K/F-2,6BPase sequences previously characterized in other vertebrates (up to $72 \%, 78 \%, 76 \%$ and $95 \%$ similarity, respectively) strongly suggests that these sequences correspond to functional proteins (enzymes or transporter). We detected only one species of PK and Glut2 mRNA in trout liver, whereas there are two FBPase and $6 \mathrm{PF}-2 \mathrm{~K} / \mathrm{F}-2,6 \mathrm{BPase}$ mRNAs. In gilthead seabream, a major hepatic 6PF-2K/F-2,6BPase RNA band of approximately $4.2 \mathrm{~kb}$ and two minor bands of approximately $2.1 \mathrm{~kb}$ and $1.1 \mathrm{~kb}$ have been detected (Meton et al., 1999a). The existence of different mRNAs may correspond either to distinct $5^{\prime}$ and $3^{\prime}$ untranslated regions or to the existence of distinct genes. Moreover, it is worth noting that trout FBPase mRNAs $(2.5 \mathrm{~kb}$ and $2.7 \mathrm{~kb}$ ) are approximately twice the size of mammalian mRNAs (approximately 1.3 and $1.5 \mathrm{~kb}$ ) (ElMagrabi et al., 1988). Furthermore, the cloning of cDNAs represented here is not exhaustive; the existence of other (different) hepatic PK, Glut2, FBPase and $6 \mathrm{PF}-2 \mathrm{~K} / \mathrm{F}-2,6 \mathrm{BPase}$ mRNAs is possible because (i) only two hepatic cDNA clones have been analysed and (ii) our cDNA cloning strategy based on RT-PCR with degenerate primers may amplify only one specific mRNA and not all the different mRNA species.

As in mammals (Marcus et al., 1987; Thorens, 1992; Pilkis et al., 1995; Yamada and Noguchi, 1999), PK, 6PF2K/F-2,6BPase, FBPase and Glut2 genes are expressed in the liver, intestine and kidney. Moreover, there is no apparent nutritional effect on the regulation of PK, Glut2, FBPase and 6PF-2K/F-2,6BPase gene expression in these different tissues, except for the FBPase gene, which is expressed in non-gluconeogenic tissues such as the muscle and heart in fed fish only. To our knowledge, the biochemical consequences of FBPase gene expression in muscle (white muscle and heart) have not been studied.

$\mathrm{PK}$ and 6PF-2K/F-2,6BPase genes code for hepatic glucose metabolism proteins that are induced by feeding in mammals (Pilkis et al., 1995; Yamada and Noguchi, 1999). Induction of hepatic trout $6 \mathrm{PF}-2 \mathrm{~K} / \mathrm{F}-2,6 \mathrm{BPase}$ gene expression by feeding (and specifically by dietary carbohydrates) in rainbow trout confirms what has been already shown in mammals and gilthead seabream (Garcia de Fructos and Baanante, 1994; Meton et al., 1999a; Meton et al., 1999b; Meton et al., 2000). However, a significant change in $6 \mathrm{PF}-2 \mathrm{~K} / \mathrm{F}-2,6 \mathrm{BPase}$ gene expression may either increase or decrease concentrations of fructose-2,6-bisphosphate; more data on the phosphorylation/dephosphorylation status of the enzyme (induced by protein kinase A or protein phosphatase 2A activities; Pilkis et al., 1995) would be needed to determine in which direction $6 \mathrm{PF}-2 \mathrm{~K} / \mathrm{F}-2,6 \mathrm{BPase}$ affects fructose-2,6bisphophate concentrations. The trout hepatic PK gene is always highly expressed, irrespective of the nutritional status. Using enzymatic methods, some authors (Cowey et al., 1977; Cowey et al., 1981; Fideu et al., 1983) found that PK activity
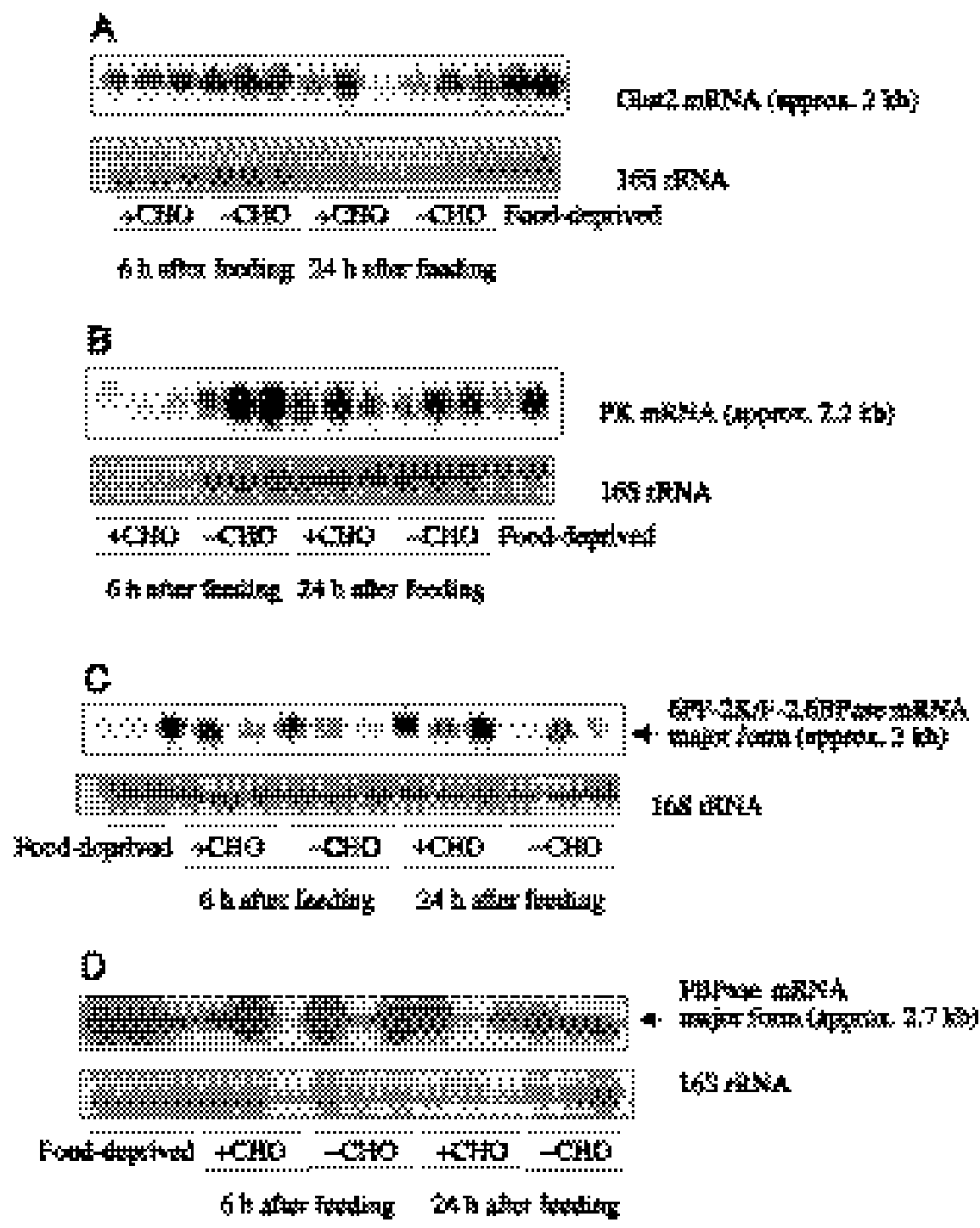

Fig. 6. Representative northern blots of 6-phosphofructo-2-kinase/fructose-2,6-biphosphatase (6PF-2K/F-2,6BPase), pyruvate kinase (PK), fructose-1,6-bisphosphatase (FBPase) and glucose transporter type 2 (Glut2) gene expression in the liver of food-deprived fish or fish fed with $20 \%$ carbohydrates $(+\mathrm{CHO})$ or without carbohydrates $(-\mathrm{CHO})$. Each band is from a different fish. The $16 \mathrm{~S}$ rRNA served as an internal control of sample loading. (A) Glut2, (B) PK, (C) 6PF-2K/F-2,6BPase, (D) FBPase. 

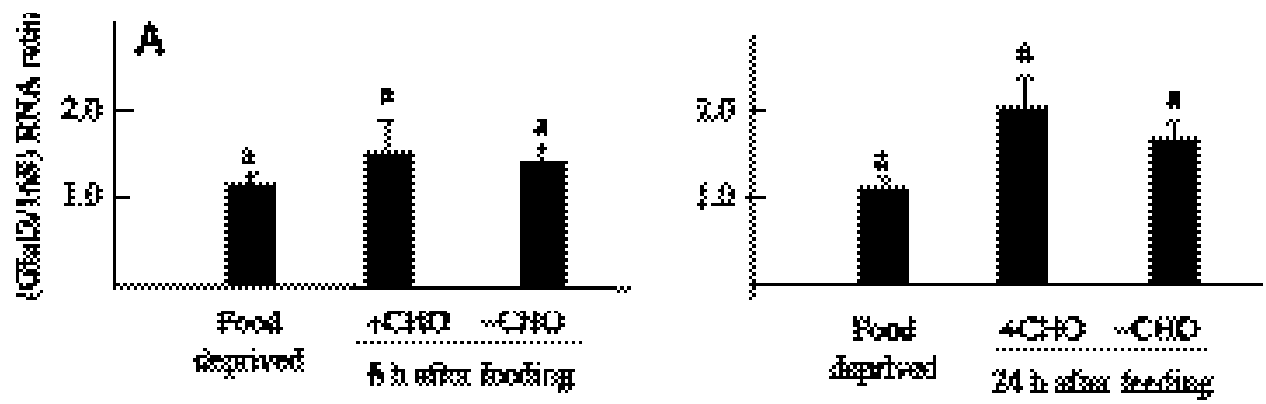

Fig. 7. Levels of 6phosphofructo-2-kinase/fructose2,6-bisphosphatase $\quad(6 \mathrm{PF}-2 \mathrm{~K} / \mathrm{F}-$ 2,6BPase), pyruvate kinase (PK), fructose-1,6-bisphosphatase (FBPase) and glucose transporter type 2 (Glut2) gene expressions in the liver of food-deprived fish and of fish fed with $20 \%$ carbohydrates $(+\mathrm{CHO})$ or without carbohydrates $\quad(-\mathrm{CHO})$. (A) Glut2, (B) PK, (C) 6PF-2K/F2,6BPase, (D) FBPase. For each gene, two different northern blots (loading with fish fed $6 \mathrm{~h}$ and $24 \mathrm{~h}$ after feeding) were done; an analysis by densitometry of mRNA levels (arbitrary units) for five fish from each treatment group weighted by $16 \mathrm{~S}$ rRNA values was performed (Visio-Mic II software). The results are expressed as means \pm S.D. $(N=5)$. Significant differences within groups are represented by different letters (Tukey's test, $P<0.05)$.

was induced by feeding in rainbow trout, while others (Hilton and Atkinson, 1982; Shikata et al., 1994) found no such induction. Our data suggest that this induction is not (mainly) due to a transcriptional mechanism, but is more probably linked either to post-transcriptional regulation or to qualitative alterations such as phosphorylation/ dephosphorylation of $\mathrm{PK}$, as in mammals (Yamada and Noguchi, 1999). Moreover, we were unable to demonstrate a significant decrease in FBPase gene expression in response to dietary carbohydrates in rainbow trout liver (at least for the major FBPase mRNA species), in accordance with the absence of inhibition of FBPase activity by dietary carbohydrates in other fish species such as perch (Perca fluviatilis) or Atlantic salmon (Salmo salar) (Tranulis et al., 1996; Borrebaek and
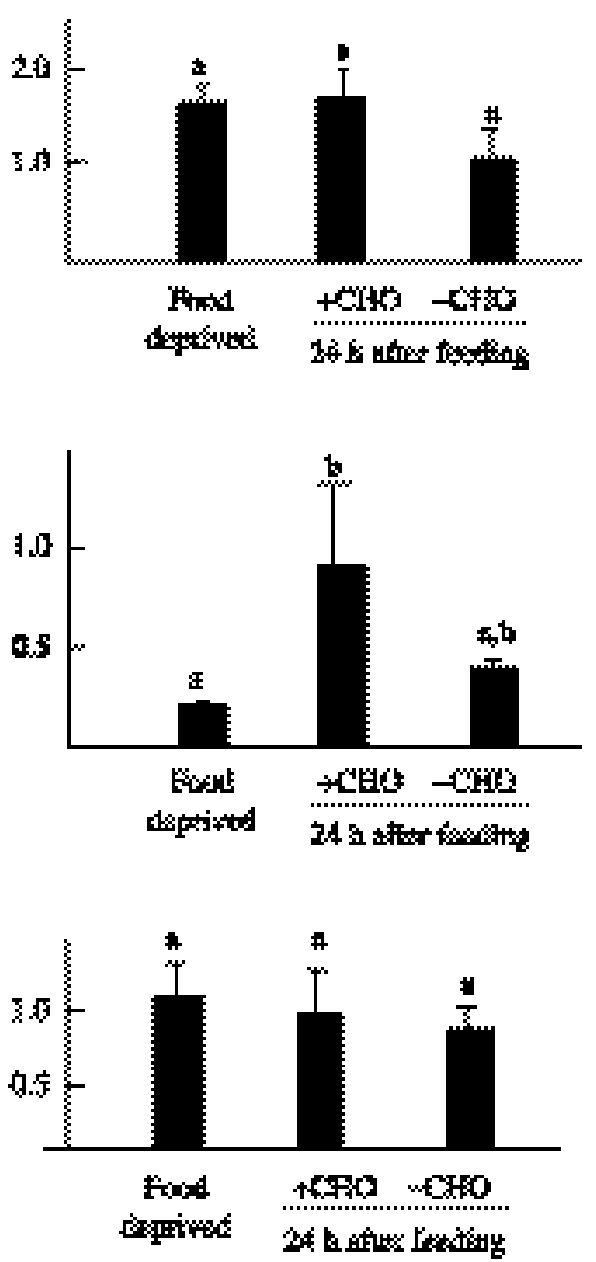

Christophersen, 2000). It is also worth noting that some individuals (irrespective of the nutritional status) show very low levels of FBPase gene expression; the explanation for this result is unknown.

Our data demonstrate the existence of a glucose transporter very similar to the mammalian Glut2 (cloning of a full-length Glut2 cDNA is in progress in collaboration with $\mathrm{Dr}$ A. Krasnov and confirms the existence of a Glut2 protein in trout; our unpublished data). Glut2 seems to be expressed at high levels in rainbow trout, irrespective of nutritional status. This result is expected since Glut2 is important for the entry of glucose into hepatocytes but to allow glucose (produced by gluconeogenesis and glycogenolysis) out of the hepatocytes during fasting (Thorens, 1992). 
In conclusion, our data demonstrate the existence of mammalian-type induction of $6 \mathrm{PF}-2 \mathrm{~K} / \mathrm{F}-2,6 \mathrm{BPase}$ gene expression by feeding, as has been shown previously for trout glucokinase (Panserat et al., 2000a; Panserat et al., 2000b) in association with high levels of PK gene expression. Taken together, these data suggest the existence of an efficient enzymatic mechanism for storing excess glucose. The existence of a type- 2 glucose transporter further supports the possibility that hepatocytes store excess dietary glucose. In contrast, FBPase is not strongly inhibited by dietary carbohydrates. Such a lack of inhibition has been observed previously for two other key hepatic enzymes, phosphoenolpyruvate carboxykinase and glucose-6phosphatase (Panserat et al., 2000a; Panserat et al., 2000b; Panserat et al., 2001), suggesting an absence of nutritional control of hepatic glucose production in trout. Further analysis of hepatic glucose production in vivo and ex vivo is necessary.

We thank F. Sandres, F. Terrier and Y. Hontang for their assistance during trials in the experimental fish farms (Donzacq, France). We are also grateful to J. Camblong and D. Bazin for their technical assistance. GenBank accession numbers: PK, AF246146; Glut2, AF246147; FBPase, AF333188; 6PF-2K/F-2,6BPase, AF246148.

\section{References}

Altschul, S., Gish, W., Miller, W., Myers, E. and Lipman, D. (1990). Basic local alignment search tool. J. Mol. Biol. 215, 403-410.

Bergot, F. (1979). Effects of dietary carbohydrates and of their mode of distribution on glyceamia in rainbow trout (Salmo gairdneri). Comp. Biochem. Physiol. 64A, 543-547.

Borrebaek, B. and Christophersen, B. (2000). Hepatic glucose phosphorylating activities in perch (Perca fluviatilis) after different dietary treatments. Comp. Biochem. Physiol. 125B, 387-395.

Chomczinski, P. and Sacchi, M. (1987). Single step method of RNA isolation by acid guanidium thiocyanate phenol chloroform extraction. Anal. Biochem. 162, 156-159.

Cowey, C. B., Knox, D., Walton, M. and Adron, J. (1977). The regulation of gluconeogenesis by diet and insulin in rainbow trout. Br. J. Nutr. 38, 463-470.

Cowey, C. B., Cooke, D. J., Matty, A. J. and Adron, J. W. (1981). Effects of quantity and quality of dietary protein on certain enzyme activities in rainbow trout. J. Nutr. 111, 336-345.

Cowey, C. B. and Walton, M. (1989). Intermediary metabolism. In Fish Nutrition (ed. J. E. Halver), pp. 259-329. New-York: Academic Press.

El-Magrabi, M. R., Pilkis, J., Fox, E., Claus, T. H. and Pilkis, S. J. (1982). Regulation of rat liver fructose-2,6-bisphosphatase. J. Biol. Chem. 257, 7603-7607.

El-Magrabi, M. R., Pilkis, J., Marker, A. J., Colosia, A. D., D'angelo, G., Fraser, B. A. and Pilkis, S. J. (1988). cDNA sequence of rat liver fructose1,6-bisphosphatase and evidence for down-regulation of its mRNA by insulin. Proc. Natl. Acad. Sci. USA 85, 8430-8434.

Fideu, M. D., Soler, G. and Ruiz-Amil, M. (1983). Nutritional regulation of glycolysis in rainbow trout (Salmo gairdneri). Comp. Biochem. Physiol. 74B, 795-799.

Garcia de Fructos, P. and Baanante, I. V. (1994). 6-phosphofructo-2kinase/fructose-2.6-bisphosphatase in liver of the teleost Sparus aurata. Arch. Biochem. Biophys. 308, 461-468.

Garcia-Rejon, L., Sanchez-Muros, M. J., Cerda, J. and De la Higuera, M. (1996). Fructose-1,6-bisphosphatase activity in livers and gonads of sea bass (Dicentrarchus labrax). Influence of diet composition and stage of reproductive cycle. Fish Physiol. Biochem. 2, 93-105.

Higgins, D. and Sharp, P. (1989). Fast and sensitive multiple sequence alignments on a microcomputer. Comp. Appl. Biosci. 5, 151-153.

Hilton, J. W. and Atkinson, J. L. (1982). Response of rainbow trout (Salmo gairdneri) to increased levels of available carbohydrate in practical trout diets. Br. J. Nutr. 47, 597-607.

Jurica, M., Mesecar, A., Heath, P., Shi, W., Nowak, T. and Stoddard, B. (1998). The allosteric regulation of pyruvate kinase by fructose-1,6bisphosphate. Structure 6, 195-210.

Ke, H., Thorpe, C. M., Seaton B. A., Marcus, F. and Lipscomb, W. N. (1989). Molecular structure of fructose-1,6-bisphosphatase at $2.8 \AA$ resolution. Proc. Natl. Acad. Sci.USA 86, 1475-1479.

Lupianez, J. A., Sanchez-Lozano, M. J., Garcia-Rejon, L. and De la Higuera, M. (1989). Long-term effect of a high-protein/non-carbohydrate diet on the primary liver and kidney metabolism in rainbow trout (Salmo gairdneri). Aquaculture 79, 91-101.

Marcus, F., Rittenhouse, J., Gontero, B. and Harrsh, P. (1987). Function, structure and evolution of fructose-2,6-bisphosphatase. Arch. Biol. Med. Exp. 20, 371-378.

Meton, I., Caseras, A., Mediavilla, D., Fernandez, F. and Baanante, I. V. (1999a). Molecular cloning of a cDNA encoding 6-phosphofructo-2kinase/fructose-2.6-bisphosphatase from liver of Sparus aurata: nutritional regulation of enzyme expresssion. Biochim. Biophys. Acta 1444, 153-165.

Meton, I., Mediavilla, D., Caseras, A., Canto, E., Fernandez, F. and Baanante, I. V. (1999b). Effect of diet composition and ration size on key enzyme activities of glycolysis-gluconeogenesis, the pentose phosphate pathway and amino acid metabolism in liver of gilthead seabream (Sparus aurata). Br. J. Nutr. 82, 223-232.

Meton, I., Caseras, A., Fernandez, F. and Baanante, I. V. (2000). 6phosphofructo-2-kinase/fructose-2.6-bisphosphatase gene expression is regulated by diet composition and ration size in liver of gilthead seabream, Sparus aurata. Biochim. Biophys. Acta 1491, 220-228.

Mommsen, T. P. and Plisetskaya, E. M. (1991). Fish insulin: history, structure and metabolic regulation. Rev. Aquat. Sci. 4, 225-259.

Moon, T. W. and Foster, G. D. (1995). Tissue carbohydrate metablism, gluconeogenesis and hormonal and environmental influences. In Biochemistry and Molecular Biology of Fishes (ed. P. W. Hochachka and T. P. Mommsen), pp. 65-100. Amsterdam, Elsevier Science Publishers.

Palmer, T. N. and Ryman, B. E. (1972). Studies on glucose intolerance in fish. J. Fish Biol. 4, 311-319.

Panserat, S., Medale, F., Blin, C., Breque, J., Vachot, C., Plagnes-Juan, E., Gomes, E., Krishnamoorthy, R. and Kaushik, S. (2000a). Hepatic glucokinase is induced by dietary carbohydrates in rainbow trout, gilthead seabream and common carp. Am. J. Physiol. 278, R1164-R1170.

Panserat, S., Médale, F., Breque, J. and Kaushik, S. (2000b). Lack of significant long-term effect of dietary carbohydrates on hepatic glucose-6phosphatase expression in rainbow trout (Oncorhynchus mykiss). J. Nutr. Biochem. 11, 22-29.

Panserat, S., Plagnes-Juan, E., Breque, J. and Kaushik, S. (2001). Hepatic phosphoenolpyruvate carboxykinase gene expression is not repressed by dietary carbohydrates in rainbow trout (Oncorhynchus mykiss). J. Exp. Biol. 204, 359-365.

Parrizas, M., Planas, J., Plisetskaya, E. M. and Gutierrez, J. (1994). Insulin binding and receptor tyrosine kinase activity in skeletal muscle of carnivorous and omnivorous fish. Am. J. Physiol. 266, R1944-R1950.

Petersen, T. D. P., Hochachka, P. W. and Suarez, R. K. (1987). Hormonal control of gluconeogenesis in rainbow trout hepatocytes: regulatory role of pyruvate kinase. J. exp. Zool. 243, 173-180.

Pilkis, S. J. and Granner, D. K. (1992). Molecular physiology of the regulation of hepatic gluconeogenesis and glycolysis. Anпи. Rev. Physiol. 54, 885-909.

Pilkis, S. J., Claus, T. H., Kurland, I. J., Lange, A. J. (1995). 6phosphofructo-2-kinase/fructose-2.6-bisphosphatase: a metabolic signaling enzyme. Annu. Rev. Biochem. 64, 799-835.

Planas, J. V., Capilla, E. and Gutierrez, J. (2000). Molecular identification of a glucose transporter from fish muscle. FEBS Lett. 481, 266-270.

Rencurel, F. and Girard, J. (1998). Regulation of liver gene expression by glucose. Proc. Nutr. Soc. 57, 265-275.

Rencurel, F., Waeber, G., Antione, B., Rocchicciolis, F., Maulard, P., Girard, J. and Leturque, A. (1996). Requirement of glucose metabolism for regulation of glucose transporter type 2 (GLUT2) gene expression in liver. Biochem. J. 314, 903-909.

Shikata, T., Iwagana, S. and Shimeno, S. (1994). Effects of dietary glucose, fructose and galactose on hepatopancreatic enzyme activities and body composition in carp. Fish Sci. 60, 613-617.

Shimeno, S., Kheyyali, D. and Shikata, T. (1995). Metabolic response to dietary carbohydrate to protein ratios in carp. Fish Sci. 61, 277-281. 


\section{S. Panserat, E. Plagnes-Juan and S. KaushiK}

Teerijoki, H., Krasnov, A., Pitkanen, T. I. and Molsa, H. (2000). Cloning and characterization of glucose transporter in teleost fish, rainbow trout (Oncorhynchus mykiss). Biochim. Biophys. Acta 1494, 290-294.

Thorens, B. (1992). Molecular and cellular physiology of GLUT-2, a high- $K_{\mathrm{m}}$ facilitated diffusion glucose transporter. Int. Rev. Cytol. 137A, 209-238.

Tranulis, MA., Dregni, O., Christophersen, B., Kroddahl, A. and Borrebaek, B. (1996). A glucokinase-like enzyme in the liver of Atlantic salmon (Salmo salar). Comp. Biochem. Physiol. 114B, 427-435.

Wilson, R. (1994). Utilisation of dietary carbohydrates by fish. Aquaculture 124, 67-80.

Wright, J. R., O’Hali, W., Yuang, H., Han, X. and Bonen, A. (1998). Glut4 deficiency and severe peripheral resistance to insulin in the teleost fish tilapia. Gen. Comp. Endocrinol. 111,20-27.

Yamada, K. and Noguchi, T. (1999). Nutrient and hormonal regulation of pyruvate kinase gene expression. Biochem. J. 337, 1-11. 